\title{
Emetophobia: sjúklegur ótti við uppköst og ógleði
}

Kolfinna Snæbjarnardóttir ${ }^{1}$ æknanemi, Engilbert Sigurðsson ${ }^{1,2}$ læknir

\section{ÁGRIP}

Emetophobia, sem nefna má uppkastafælni, er áköf og órökrétt hræðsla tengd uppköstum og ógleđi. Emetophobia er flokkuð sem sértæk fælni í alpjóðlegum flokkunarkerfum. Pessi kvilli er dulinn í mörgum tilfellum hjá polendum par sem peir skammast sín fyrir sjúkdóminn, og hefur hann pví lítið verið rannsakaður samanborið við flestar kvíðaraskanir. Fátt er pví vitað um algengi uppkastafælni, meðferð og afdrif. Lýst er konu á fertugsaldri sem glímt hefur við uppkastafælni frá barnæsku, par sem hún upplifði slæma gubbupest tvö aðfangadagskvöld í röð. ÆE síðan hefur ótti við uppköst litað margt í daglegu lífi hennar.
Læknadeild Háskóla islands, ${ }^{2}$ geðsviði Landspítala Hringbraut

Fyrirspurnir: Engilbert Sigurðsson engilbs@/sh.is

Greinin barst 11. janúar 2014, sampykkt til birtingar

26. mars 2014

\section{Inngangur}

Uppkastafælni (emetophobia), eða áköf og órökrétt hræðsla tengd uppköstum, hefur hingað til verið flokkuð sem sértæk kvíðaröskun í alpjóðlegum flokkunarkerfum og pá í flokki sértækrar fælni. Pessi kvilli hefur pó verið dulinn í mörgum tilfellum hjá polendum og pví lítið rannsakaður samanborið við flestar kvíðaraskanir.1.-3 Kenningar hafa verið settar fram um að uppkastafælni falli í eðli sínu vart í flokk sértækrar fælni. Hún sé fremur undirflokkur felmtursröskunar eða félagsfælni, í raun kvíðaröskun með fælnipætti par sem polendur forðast aðstæður sem gætu leitt til uppkasta., ${ }^{1,2}$ Einnig hefur hún verið talin skarast við áráttu og práhyggjuröskun. ${ }^{2}$ Hins vegar er ljóst að pessi kvíðaröskun getur líkt og sumar aðrar kvíðaraskanir verið prálát og valdið miklu álagi í einkalífi, vinnu og hamlað félagslegri virkni. Hún getur einnig valdið pví að konur forðast eða seinka pví að eignast börn. ${ }^{4}$

Margt er enn á huldu um algengi uppkastafælni, par sem pað hefur lítið verið rannsakað., ${ }^{2,4}$ Eina stóra faraldsfræðirannsóknin sem lagði mat á algengi sértækar fælni og greindi uppkastafælni frá, taldi algengi hennar vera $0,1 \% .{ }^{5}$ Petta kann að vera vanmat, par sem einkenni uppkastafælni skarast oft við einkenni felmtursröskunar, heilsukvíða, áráttu og práhyggju og jafnvel við lystarstol (tafla I). ${ }^{6}$ Mat nokkurra annarra rannsakenda á algengi uppkastafælni er allt frá 1,7 til 3,1\% hjá körlum og frá 6 til 7\% hjá konum. ${ }^{3,7,8}$ Hér ber mikið í milli. Erfitt hefur reynst að finna mun milli kynja í sumum rannsóknum ${ }^{6}$ en í öðrum hafa konur verið í miklum meirihluta, ${ }^{4,6}$ líkt og á við um flestar kvíðaraskanir. ${ }^{4}$

Erfitt er að rannsaka sjúkdóminn, ekki síst vegna lítilla tengsla pessa hóps við heilbrigðiskerfið. Fólk með uppkastafælni virðist almennt ekki leita sér aðstoðar nema pað veikist af öðrum sjúkdómum, svo sem punglyndi eða annarri kvíðaröskun. Раð er hugsanlega vegna pess að pað skammast sín iðulega fyrir uppkasta- fælnina., 10 Einnig kemur fram í umfjöllun polenda á internetinu að pað geri peim erfitt um vik að fáir læknar viti hvað uppkastafælni er og margir viti í raun ekki að uppkastafælni sé til. ${ }^{9-11}$

Konan sem hér er til umfjöllunar hefur glímt við uppkastafælni frá barnsaldri. Pessi órökrétti kvíði og hliðrun hefur háð henni allar götur síðan. Hún á góð og slæm tímabil en er aldrei einkennalaus. Að pví leyti minnir gangurinn frekar á áráttu og práhyggju eða félagskvíða en á felmtursröskun. Tilgangurinn með birtingu pessa sjúkratilfellis er að vekja athygli á pessari duldu og ef til vill sjaldgæfu kvíðaröskun og til að auka pekkingu heilbrigðisstarfsmanna og almennings á pessum kvilla. Með pví móti væntum við að auðveldara verði fyrir polendur að leita sér hjálpar og fyrir fagfólk að greiða götu peirra.

\section{Sjúkratilfelli}

Um er að ræða vel menntaða konu á fertugsaldri, í góðu starfi og í hjónabandi. Hún á börn á leikskólaaldri. Konan hefur aldrei reykt né notað áfengi eða aðra vímugjafa. Hún hefur haft kvíða og uppkastafælni frá barnsaldri og hefur nokkrum sinnum legið á geðdeild vegna pessa, og stundum jafnframt með punglyndiseinkenni. Gegnum tíðina hefur hún reynt mörg meðferðarúrræði við sinni uppkastafælni en ekkert af peim hefur borið góðan árangur að hennar mati. Hún hefur einnig farið í ítarlegt greiningarviðtal með tilliti til átröskunarsjúkdóms en engin slík einkenni komu par fram. Sjálf segir hún átröskun aldrei hafa verið vandamál hjá sér.

Upphaf einkenna sjúklings má rekja til pess að hún fékk gubbupest tvö aðfangadagskvöld í röð, sjö og átta ára gömul. Á aðfangadag ári síðar fékk hún fyrsta ofsakvíðakastið. Síðan hefur hún jafnan tengt uppköst við minningar um að hafa eyðilagt jólin fyrir fjölskyldunni. 
Tafla I. Einkenni tengd uppkastafælni.

\begin{tabular}{l}
\hline Ofsakvíðaköst \\
\hline Kvíði og depurð \\
\hline Öryggishegðun og forðun \\
\hline Meltingafæraeinkenni \\
\hline Hömlun félagslegrar virkni \\
\hline
\end{tabular}

Pessa reynslu hefur hún æ síðan yfirfært á aðra viðburði og óttast mjög að hún gæti skemmt fyrir sér og öðrum viðburði sem framundan eru með pví að verða óglatt eða kasta upp. Til dæmis má par nefna skólaskemmtanir, partý, bústaðaferðir og bíóferðir par sem hún kýs að sitja í endasæti til pess að eiga greiða útgönguleið gerist pess pörf. Margur myndi ætla að uppköst kynnu að viðhalda vandanum en konan hefur raunar ekki kastað upp í nær tvo áratugi. Pað má vera að fælni hennar við að kasta upp sé enn alvarleg par sem hún hefur ekki kastað upp svo lengi og pví ekki upplifað að ótti hennar fjari út við pað. Barnæska sjúklings og unglingsár lituðust af hræðslu hennar við uppköst og umgangspestir og allt sem gæti mögulega gert hana veika. Hún var með ýmiss konar áráttu sem barn, purfti til dæmis að berja tannburstanum prisvar í vaskinn, rífa klósettpappírinn beint, setja lakið alltaf fyrst á sama hornið á rúminu pegar hún bjó um og svo framvegis. Með pví að gera petta taldi hún sig sleppa við veikindi.

Sjúklingur hefur átt bæði góð og slæm tímabil í lífinu eins og gengur. Hún hefur upplifað mikinn kvíða á meðgöngu og veikst af alvarlegu fæðingarpunglyndi og kvíða eftir prjár fæðingar. Hún fær endurtekið slæm kvíðaköst ef gubbupest er að ganga í kringum hana. Hún fer oftast út af heimilinu ef fjölskyldumeðlimur veikist og getur ekki annast börn sín pegar pau fá gubbupest. Рað er ýmislegt sem hún hefur forðast algjörlega til að finna ekki fyrir ógleði eða verða ekki veik. Hún fer til dæmis ekki á sjó, ekki í tívolítæki, drekkur ekki áfengi, borðar ekki yfir sig, er hrædd við að neyta sumra fæðutegunda, verður kvíðin í flugvélum og á erfitt með langar bílferðir með börnunum par sem pau eiga pað til að verða bílveik (tafla II).

Öryggishegðun hennar er afar víðtæk. Hún les stöðugt í atferli peirra sem hún umgengst til að reyna að sjá hvort fólk sé við góða heilsu eða kunni að vera með pest. Til dæmis ef börnin borða óvenju lítið af einhverju sem peim pykir gott eða eru föl á hörund fer hún að hafa áhyggjur. Undanfarin ár hafa kvöldin og næturnar verið erfiðastar, hún dregur pað sem lengst að fara að sofa pví að hún bíður eftir að börnin kunni að vakna og fari að kasta upp. Henni finnst fólk almennt oftar veikjast með slíkum einkennum á næturnar. Eftir að hún varð móðir hefur hún átt erfitt með að vera ein með börnum sínum yfir nótt af ótta við að hún geti ekki annast pau nægilega vel ef veikindi koma upp.

Hún lagðist fyrst inn á geðdeild fyrir nokkrum árum. Innlagnir hennar urðu svo heldur tíðari um skeið pegar yngsta barnið komst á leikskólaaldur.

\section{Meðferðir og afdrif}

Sem barn og unglingur fór sjúklingur til ýmissa sálfræðinga og geðlækna en fannst enginn skilja vandamálið. Kvíðalyf voru reynd, til dæmis alprazólam og díazepam, með takmörkuðum árangri en pau hjálpuðu henni ef til vill yfir erfiðustu hjallana. Fyrsta og nær eina langtímalyfjameðferð hennar hefur verið með punglyndis- og kvíðalyfinu sertralín. Sú meðferð hófst fyrir um 10 árum í kjölfar fyrstu fæðingar. Hún hefur náð ágætis tímabilum á sertralíni en slæmir kaflar koma pó áfram inn á milli, oft tengdir umgangspestum. Í seinni tíð hefur stundum nægt að lesa stöðuuppfærslur á Facebook um umgangspestir eða veikindi barna sem börn hennar umgangast. Hún tók auk sertralíns lágskammta perfenazín og oxazepam eftir pörfum samhliða pví að hitta sálfræðing og fara í gegnum byrjunarstig hugrænnar atferlismeðferðar (HAM) og gera tilraun til kerfisbundinnar ónæmingar vegna fælninnar.

Rétt eftir að yngsta barn hennar fæddist fyrir nokkrum árum sökk hún pað djúpt að hún lagðist í fyrsta sinn inn á geðdeild Landspítalans. Henni hafði raunar liðið betur eftir pessa síðustu fæðingu en hinar fyrri, en svo herjaði gubbupest á heimilið. Раð varð til pess að hún svaf lítið og illa í lengri tíma, nærðist illa og líðan hennar versnaði mikið. Fékk hún meðal annars sjálfsvígshugsanir. Eftir pessa fyrstu innlögn byrjaði hún aftur í vikulegum tímum hjá geðlækni og sálfræðingi. Fáein ár liðu. Snemma árs 2011 var sertralíni skipt út og buspiron reynt. Hún tók buspiron í 6 vikur, en líðan hennar versnaði og hún hætti að taka lyfið í samráði við geðlækninn. Var pá lyfjalaus um nokkurt skeið. Pá prófaði hún um hríð aðferð sem hefur sýnt gagnsemi við meðferð áfallastreitu, EMDR (eye movement desensitization and reprocessing), ásamt dáleiðslu, með litlum sem engum árangri. Seinni part ársins fór henni að versna mikið og hún lagðist prisvar inn á geðdeild á fremur stuttu tímabili. Рað sem orsakaði pessar innlagnir var svefnleysi, lystarleysi, kvíði og sjálfsvígshugsanir sem komu og fóru í nokkra daga í hvert sinn vegna veikinda barnanna eða pesta sem voru að ganga í skólum peirra. Fyrir vikið missti hún stjórn á kvíðanum. Eftir að henni fór að versna hafa verið reynd fleiri punglyndislyf sem sýndu ekki marktæka virkni á nokkrum mánuðum. Hún er í dag á paroxetíni sem hún hefur tekið í um eitt ár, auk pess sem hún parf einstaka sinnum að nota róandi lyf eins og lorazepam og prómetazín. Dagleg líðan hefur breyst mikið til hins betra og hún er í mun betra jafnvægi. Hún fær enn slæm kvíðaköst par sem hún heldur að hún purfi að kasta upp en köstin standa nú yfir í mun skemmri tíma en pau gerðu áður og eru pess vegna viðráðanlegri.

\section{Umræða}

Erfitt hefur reynst að skilja meingerð uppkastafælni. Víðtækasta yfirlitið til pessa var birt $2001^{4}$ par sem kynntar voru niðurstöður netkönnunar meðal 56 sjálfvaldra einstaklinga. Prátt fyrir að pessi hópur væri ekki slembivalinn og ekki með staðfesta greiningu, eru niðurstöður pessarar rannsóknar nothæfar sem eins konar forrannsókn eða upphafspunktur til að reyna að skilja gang sjúkdómsins. Í könnuninni kom fram að einkenni uppkastafælni hefðu byrjað mjög snemma hjá pátttakendum, oft í barnæsku (til dæmis í kjölfar áfalla, eftir að hafa fengið erfiða gubbupest eða séð aðra kasta upp), og væru ósjaldan prálát með fáum sjúkdómshléum. ${ }^{4,9}$ Pessi óheppilega skilyrðing og tenging uppkastafælni við margt í daglegu lífi ylli iðulega miklu álagi og nokkurri fötlun hjá mörgum sem við sjúkdóminn glímdu. Flestir höfðu mestar áhyggjur af pví að kasta upp sjálfir frekar en að lenda í pví að aðrir köstuðu upp í peirra viðurvist. Stór hluti pátttakenda í pessari 
Tafla II. Algeng öryggishegðun hjá einstaklingum með uppkastafælni.

Forðast áfengi eða halda neyslu pess í lágmarki.

Athuga ítrekað „best fyrir" dagsetningar á mat.

Forðast siglingar og flug með litlum flugvélum.

Forðast almenningssamgöngur, kjósa frekar að aka eigin bíl.

Að finnast ópægilegt að fara í bíc eða leikhús, velja endasæti.

Forðast að verða barnshafandi vegna hræðslu við morgunógleði og vegna ótta við að geta ekki sinnt barninu pegar pað veikist.

Borða sjaldan á veitingahúsum og forðast óvenjulega eldaðan mat.

Forðast bari og skemmtistaði.

Forðast matarboð og mannpröng.

Borða sjaldan á almannafæri og sitja pá helst nálægt útgangi.

rannsókn lýsti kvíðaköstum ótengdum uppkastafælninni. Í pessum tilfellum fundu $80 \%$ sjúklinga fyrir meiri/fleiri einkennum frá meltingarfærum, sem voru hluti einkenna kvíðakasta. ${ }^{4}$ Önnur rannsókn frá $2006{ }^{12}$ par sem 100 sjúklingar lýstu einkennum uppkastafælni sýndi að öryggishegðun og forðun (til dæmis að athuga ítrekað lokasöludag matvæla, forðast áfengi og aðra vímugjafa, sneiða hjá fuglakjöti og sjávarfangi, forðast einstaklinga sem gæu verið veikir eða smitandi, forðast drukkið fólk og ferðir til útlanda, hliðra sér hjá sjóferðum og velja að eignast ekki börn) voru einkennandi fyrir fólk með uppkastafælni. ${ }^{6,12}$ Pessari öryggishegðun er lýst í fleiri greinum en pví er einnig lýst að sumir sjúklingar forðist mat svo mikið að peir verði vannærðir. ${ }^{6}$ Í báðum rannsóknum kom fram að innvortis skynjun eða einkenni væru driffjöður kvíðans hjá mörgum sem pjást af uppkastafælni. ${ }^{4,12}$

Mikið virðist vera um fylgisjúkdóma samhliða uppkastafælni. Fram kom að 30\% sjúklinga með uppkastafælni hefðu aðrar sértækar raskanir: 40\% sögðust vera með felmtursröskun eða víðáttufælni, 46\% með punglyndi, 21\% með félagsfælni og 18\% með áráttu- og práhyggjuröskun. ${ }^{4}$ Pessum fylgisjúkdómum, ásamt ýmsum einkennum frá meltingarfærum, hefur einnig verið lýst í öðrum greinum. ${ }^{1,2,4}$

Meðferð uppkastafælni hefur einungis verið skoðuð í örfáum rannsóknum. Rannsóknirnar hafa einkum metið berskjöldun með svarhömlun (exposure response prevention) og kerfisbundna ónæmingu. ${ }^{1,2}$ Samkvæmt einni rannsókn er algengast að sjúklingar með uppkastafælni séu meðhöndlaðir á pann hátt að peir séu útsettir fyrir kveikjum. ${ }^{3}$ Eins og gefur að skilja getur pað verið mjög flókið að framkvæma uppköst hjá sjúklingum með uppkastafælni. Pess í stað hefur oft verið reynt að sýna peim myndbönd af fólki að kasta upp. ${ }^{3,13}$ Teknar hafa verið saman niðurstöður par sem berskjöldun í ýmsu formi hefur verið notuð og nefna má sem dæmi rannsókn frá $1983{ }^{13}$ par sem kvíðastig sjúklinga lækkaði úr 7 í 1 á skalanum 1 til 10 með pví að nota upptökur og með berskjöldun par sem einn meðferðaraðilanna póttist kasta upp. Á svipaðan hátt voru notaðar ${ }^{7}$ upptökur af uppköstum til meðhöndlunar á 7 sjúklingum með hræðslu við uppköst. Sú nálgun bar árangur í öllum tilfellunum í 8 til 13 meðferðartímum. ${ }^{3}$ Ýmis afbrigði annars konar meðferðar hafa sýnt árangur við meðhöndlun uppkastafælni hjá hluta polenda: Dáleiðsla, hugræn atferlismeðferð, áhugahvetjandi samtal, fræðsla og geðlyf. ${ }^{3}$ Teknar voru saman niðurstöður nokkurra rannsókna par sem lyfjameðferð við sértækri fælni (par á meðal uppkastafælni) er skoðuð. Par er talið að pær sýni að SSRI lyf (selective serotonin reuptake inhibitors) eins og sertralín og paroxetín hjálpi að minnsta kosti hluta sjúklinga með sértæka fælni að ná bata, og að jafnan ætti að íhuga SSRI lyfjameðferð við uppkastafælni. ${ }^{2}$ Virkni peirra meðferða sem nefndar eru hér á undan er pó mismunandi, einstaklingsbundin að hluta og vandmetin, enda erfitt að ná til nægilega margra slíkra sjúklinga til að gera vandaðar meðferðarrannsóknir. Kjarni flestra annarra meðferðarúrræða en lyfjameðferðar er berskjöldun með svarhömlun. ${ }^{3}$

Rannsóknir á meðferð við uppkastafælni hafa leitt í ljós mismikinn árangur. Algengt er að meðferð með berskjöldun virki en pað er pó alls ekki algilt. Meðferð með lyfjum hefur einnig mismikil áhrif. Rannsókn sýndi að 34\% sjúklinga höfðu gagn af lyfjameðferð, en helmingur peirra notaði geðlyf, hinn helmingurinn önnur lyf eins og ofnæmislyfið prómetazín (betur pekkt sem sérlyfið Phenergan) og magalyfið ranitidine. Margir forðuðust lyf vegna hræðslu við ógleði. ${ }^{4}$

\section{Samantekt}

Sjúkrasagan sem rakin er að ofan svipar um margt til „dæmigerðra“ tilfella af uppkastafælni, sé tekið mið af birtum rannsóknum. Svipuð mynd kemur fram á bloggsíðum og upplýsingasíðum um uppkastafælni á netinu ${ }^{9-11}$ par sem oft má rekja upphaf uppkastafælni til slæmrar reynslu af uppköstum í æsku og að versna síðar virðist mjög oft tengjast umgangspestum og barneignum. Öryggishegðun polenda er mikil og horfur eru enn óljósar. Einkennin sveiflast frá einum tíma til annars en eru í sumum tilfellum prálát og geta varað í ár og jafnvel áratugi. Par sem uppkastafælni er lítt pekkt og nokkuð dulið form kvíðaröskunar, og polendur kunna að skammast sín fyrir vanmátt sinn, ekki síst mæður með lítil börn, er mikilvægt að læknar hafi sjúkdóminn í huga við greiningu og meðhöndlun kvíða pegar einhver einkenni uppkastafælni eru til staðar.

\section{Pakkir}

Við pökkum Magnúsi Haraldssyni geðlækni yfirlestur handrits og gagnlegar ábendingar. 


\section{Heimildir}

1. Williams KE, Field DG, Riegel K, Paul C. Brief. Intensive Behavioral Treatment of Food Refusal Secondary to Emetophobia. Clin Case Studies 2012; 10: 304-11.

2. Boschen MJ. Reconceptualizing Emetophobia: a CognitiveBehavioral Formulation and Research Agenda. J Anxiety Disord 2007; 21: 407-19.

3. Hunter PV, Anthony MM. Cognitive-Behavioral Treatment of Emetophobia: The Role of Interoceptive Exposure. Cogn Behav Practice 2009; 16: 84-91.

4. Lipsitz JD, Fyer AJ, Paterniti A, Klein DF. Emetophobia: Preliminary Results of an Internet Survey. Depress Anxiety 2001; $14: 149-52$
5. Becker ES, Rinck M, Turke V, Kause $\mathrm{P}$, Goodwin R, Neumer S, et al. Epidemiology of Specific Phobia Subtypes: Findings from the Dresden Mental Health Study. Eur Psychiatry 2007; 22: 69-74.

6. Veale D, Murphy P, Ellison N, Kanakam N, Costa A Autobiographical Memories of Vomiting in People with a Specific Phobia of Vomiting (Emetophobia). J Behav Ther Exp Psychiatry 2013; 44: 14-20.

7. Philips HC. Return of Fear in the Treatment of a Fear of Vomiting. Behav Res Ther 1985; 23: 45-52.

8. van Hout WJ, Bouman TK. Clinical Features, Prevalence and Psychiatric Complaints in Subjects with Fear of Vomiting. Clin Psychol Psychother 2012; 19: 531-9.
9. www emetophobia com - september 2013

10. livingwithemetophobia.blogspot.com/ - september 2013.

11. www.emetophobiahelp.org/fact-sheet.html - septembe 2013.

2. Veale D, Lambrou C. The Psychopathology of Vomit Phobia. Behav Cogn Psychother 2006; 34:139-50.

13. McFadyen M, Wyness J. You Don't Have to be Sick to be a Behaviour Therapist but it can Help! Treatment of a "Vomit" Phobia. Behav Psychother 1983; 11: 173-6.

ENGLISH SUMMARY

\section{Emetophobia: morbid fear of vomiting and nausea}

Kolfinna Snaebjarnardottir ${ }^{1}$, Engilbert Sigurdsson ${ }^{1,2}$

Emetophobia is an intense, irrational fear or anxiety of or pertaining to vomiting. It is classified among specific phobias in ICD-10 and DSM-IV. This disorder is often hidden because of the shame associated with it among sufferers. As a result emetophobia has been studied less than most other anxiety disorders. Not much is known about the epidemio-

logy, treatment and outcome of this disorder. We describe a woman in her thirties who has been living with emetophobia since she experienced emesis two successive Christmas Eves as a child. Subsequently her fear of vomiting has influenced many aspects of her daily life.

Key words: Emetophobia, vomiting, emesis, anxiety disorder, specific phobia.

Correspondence: Engilbert Sigurðsson, engilbs@landspitali.is

${ }^{1}$ Faculty of Medicine, School of Health Sciences, University of Iceland, ${ }^{2}$ Mental Health Services, Landspitali-National University Hospital. 